\title{
The significance of the nursing actions in psychiatric hospitalization of female adolescent users of psychoactive substances
}

\author{
O significado das ações de enfermagem na internação de \\ adolescentes usuárias de substâncias psicoativas \\ El significado de las acciones de enfermería en la internación psiquiátrica \\ de mujeres adolescentes usuarias de sustancias psicoactivas
}

\section{Rita Mello de Melloa Jacó Fernando Schneider ${ }^{b}$ Cíntia Nasib Marcio Wagner Camatta ${ }^{b}$ Eglê Rejane Kohlrausch ${ }^{\text {b }}$ Annie Jeanninne Bisso Lacchinic Tainá Moreira de Mello ${ }^{\mathrm{b}}$}

\section{How to cite this article:} Mello RM, Schneider JF, Nasi C, Camatta MW, Kohlrausch ER, Lacchini AJB, Melo TM. The significance of the nursing actions in psychiatric hospitalization of female adolescent users of psychoactive substances. Rev Gaúcha Enferm. 2021:42:e20200011. doi: https://doi. org/10.1590/1983-1447.2021.20200011
Universidade do Vale do Rio dos Sinos (UNISINOS) São Leopoldo, Rio Grande do Sul, Brasil.

- Universidade Federal do Rio Grande do Sul (UFRGS). Escola de Enfermagem. Porto Alegre, Rio Grande do Sul, Brasil.

Universidade Federal de Ciências da Saúde de Porto Alegre (UFCSPA), Departamento de Enfermagem. Porto Alegre, Rio Grande do Sul, Brasil.

\section{ABSTRACT}

Objective: To understand the significance of the actions developed by the nursing team in a Psychiatric Inpatient Unit for adolescent female users of psychoactive substances in the light of Alfred Schutz's phenomenological sociology framework.

Method: Qualitative study with Alfred Schutz's Phenomenological Sociology approach. Four nurses and 17 nursing assistants and technicians from a General Hospital in the city of Porto Alegre participated in the study.

Results: Three concrete categories emerged: nursing actions as being-with-the-other; collective nursing actions as a potential for shared act and nursing actions as expectations and challenges.

Final considerations: The actions developed by the nursing team are established through intersubjective relationships, based on bonding and dialogue, but there is still a need for nursing to enhance its actions by expanding the offer of collective therapeutic activities aligned with the psychosocial care model.

Keywords: Nursing. Substance-related disorders. Mental health. Hospitalization. Adolescent.

\section{RESUMO}

Objetivo: Compreender o significado das ações desenvolvidas pela equipe de enfermagem em uma Unidade de Internação Psiquiátrica de adolescentes usuárias de substâncias psicoativas à luz do referencial da sociologia fenomenológica de Alfred Schutz. Método: Estudo qualitativo com abordagem da Sociologia Fenomenológica de Alfred Schutz. Participaram do estudo quatro enfermeiros e 17 auxiliares e técnicos de enfermagem de um Hospital Geral do município de Porto Alegre.

Resultados: Emergiram três categorias concretas: ações de enfermagem enquanto ser-com-0-outro; ações coletivas de enfermagem enquanto potencial do agir compartilhado e ações de enfermagem enquanto expectativas e desafios.

Considerações finais: As ações desenvolvidas pela equipe de enfermagem são estabelecidas por meio de relações intersubjetivas, pautadas pelo vínculo e diálogo, porém ainda há a necessidade de a enfermagem potencializar suas ações mediante a ampliação de oferta de atividades terapêuticas coletivas consoantes com o modelo de atenção psicossocial.

Palavras-chave: Enfermagem. Transtornos relacionados ao uso de substâncias. Saúde mental. Hospitalização. Adolescente

\section{RESUMEN}

Objetivo: Comprender el significado de las acciones desarrolladas por el equipo de enfermería en Unidad de Internación Psiquiátrica para mujeres adolescentes usuarias de sustancias psicoactivas, considerando el referencial de la sociología fenomenológica de Alfred Schutz. Método: Estudio cualitativo basado en la Sociología Fenomenológica de Alfred Schutz. Participaron cuatro enfermeros y 17 auxiliares de enfermería y técnicos de una unidad de hospitalización psiquiátrica en hospital general de la ciudad de Porto Alegre.

Resultados: Surgieron tres categorías concretas: acciones de enfermería sobre estar-con-el-otro; operaciones colectivas de enfermería como potencial de acción compartida y las acciones de enfermería como expectativas y desafíos.

Consideraciones finales: Las acciones desarrolladas por el equipo de enfermería se establecen a través de relaciones intersubjetivas, guiadas por el vínculo y el diálogo, pero aún se demarca la necesidad de la enfermería de potencializar sus acciones ampliando la oferta de actividades terapéuticas colectivas alineadas con el modelo de atención psicosocial.

Palabras clave: Enfermería. Trastornos relacionados con sustancias. Salud mental. Hospitalización. Adolescente. 


\section{IINTRODUCTION}

Faced with a capitalist society strongly allied to consumerism, an increase in the use of psychoactive substances is revealed, especially in adolescence. A fact that has concerned parents, educators and health professionals, requiring that prevention, promotion and combating strategies for the use of psychoactive substances be put into practice ${ }^{(1)}$.

The Psychosocial Care Network (Rede de Atenção Psicossocial - RAPS) is in direct dialogue with Law 10.216/2001 - Psychiatric Reform Law -, and predicts a diversified composition of services with an emphasis on the territory and the importance of an interdisciplinary work. But despite the advances in mental health that are now discussed from the perspective of longitudinality of care, we still find many obstacles with regard to this care network, in particular, care for adolescent users of psychoactive substances ${ }^{(2)}$.

Adolescence is a phase of radical changes, in which young people experience significant discoveries in search of affirming their individuality and personality. It is a critical stage that comprises its transformation until adulthood, in which drugs may be more present, and are even related to the relief of the anguish inherent to the human condition. It is a period of risks, in which the adolescent is in this transitional phase between childhood and adulthood, in which the importance of an adult's care to ensure the satisfaction of their basic needs such as food, education and living the love, but without yet having learned to tolerate and face their instincts for new discoveries and desire for recognition and belonging in the group ${ }^{(3)}$.

The care provided by nursing directed to adolescents users of psychoactive substances can include actions aimed at promoting physical and mental well-being with the centrality of dialogue as a space for expressing the adolescent's needs, constituting an important way to establish communication and therapeutic relationship. Nursing can also include in its actions emancipatory perspectives of adolescents, aiming at the prevention of drug use and health promotion, with an ethical approach that considers their context and subjectivity ${ }^{(4)}$.

In psychiatric inpatient units, nursing has been progressively changing its performance, from an approach of valuing drug treatment, distancing from direct care due to bureaucratic activities ${ }^{(5)}$ development of assistance activities of technical nature; for another investment in the therapeutic relationship, giving priority to the user's subjectivity, the therapeutic and organizational environment. In addition, it has been proposing comprehensive and specialized care, to achieve the well-being and deinstitutionalization of users, acting in a scientific, systematized and humanized way ${ }^{(6)}$.
In order to contribute to this debate, the guiding question emerges in the present study: What is the significance of the actions of the nursing team in a psychiatric inpatient unit for female adolescent users of psychoactive substances? For this study, action is understood as the conduct based on a project. It is directly linked to thoughts, planning and interest, that is, its interpretation is based on the stock of knowledge related to the experience of each one who is in constant transformation ${ }^{(7)}$.

From listening to professionals, it is possible the reflection on their practices and the production of new technologies. Thus, the objective of the study is to understand the significance of the actions developed by the nursing team in a Psychiatric Inpatient Unit for female adolescent users of psychoactive substances in the light of Alfred Schutz's phenomenological sociology framework.

\section{$\square$ METHOD}

It is a qualitative research, of phenomenological nature, based on Alfred Schutz's Phenomenological Sociology ${ }^{(7)}$. The significance of the actions unveiled in this study concerns the motivated behavior of the nursing team, that is, the reasons why, as an objective category, accessible to the observer who reveals itself, when we look retrospectively at past experiences, directly related to the project of the action. And the reasons for, which refer to becoming, what is intended, is essentially subjective, being accessible only when asked to the actor.

The research scenario was a female psychiatric inpatient unit for adolescent users of psychoactive substances in a public general hospital of reference in the southern region of the country. It offers eight SUS beds for adolescents aged 12 to 17 years and 11 months. The treatment in this unit includes detoxification, treatment of chemical dependency, psychiatric comorbidities, family follow-up and continuation of post-discharge treatment ${ }^{(8)}$.

The occupation of beds in this Unit takes place by the Regulation Center of the Municipality of Porto Alegre, via Emergencies in Mental Health or consultancies sent by the Internal Units of the Hospital to the Psychiatric Inpatient Unit ${ }^{(8)}$.

The research participants were four nurses and 17 nursing assistants and technicians from the psychiatric inpatient unit of this general hospital. The inclusion criteria was to be a female nursing worker of the female psychiatric inpatient for adolescents for at least six months. The exclusion criteria were being on vacation and/or leave during the period of information collection. The nursing team was exclusively from this unit. 
The information collection was carried out through phenomenological interviews from October to November 2018. The interviewees were individual, applied by the researcher and scheduled. They took place in a room at the unit, without compromising the operation of the service, with an average duration of 40 minutes. The statements were recorded and transcribed in their entirety, ensuring the veracity of the data. In the transcription stage, a double check of the transcripts was carried out, and the interviews and transcripts were made by the researcher herself.

For the interviews, the following questions were used: "How do you develop your nursing actions in the psychiatric inpatient unit of female adolescent users of psychoactive substances?";"What do you expect with your nursing actions in the psychiatric inpatient unit of female adolescent users of psychoactive substances?" and "What are the difficulties and potential in your nursing actions?". For purposes of privacy of the participants, the speeches were referenced by the letter "I" of interviewees, followed by the interview number.

The analysis of the information took place in the light of Alfred Schutz's phenomenological sociology framework ${ }^{(7)}$. To understand the significance of nursing actions in a psychiatric inpatient unit for female adolescent users of psychoactive substances, the following steps recommended by researchers of this framework were followed(9): attentive reading of the statements in order to capture the information, taking into account the research objectives; identification of the concrete categories that house the subjects' actions; rereading the speeches to select and group excerpts that contained similar significant aspects of the subjects'actions; and, finally, based on the typical characteristics of the speeches, the significance of the subjects'actions was established, seeking to describe the typical of the action of the nursing team.

From the convergences of the units of significance that emerged from the speeches, the results of the experiences of the nursing team were organized into three concrete categories: "nursing actions as being-with-the-other"; "collective nursing actions as a shared act" and "nursing actions as expectations and challenges". At the end of the analysis process, the feedback of the results was scheduled with the inpatient unit, in order to contribute to the care of female adolescent users of psychoactive substances.

The ethical aspects of research with human beings, recommended by the National Health Council, were complied with, in accordance with Resolutions number 466/2012 and number 510/2016. This study was approved by the Research Ethics Committee of the institution, under CAEE 94286418.7.0000.5530. All participants signed the Free and Informed Consent Form (FICF).

\section{RESULTS AND DISCUSSION}

From the analysis of the reports in the light of Alfred Schutz's phenomenological sociology framework ${ }^{(7)}$, three concrete categories are presented: nursing actions as being-with-the-other, collective nursing actions as potential for shared act, and nursing actions as expectations and challenges.

\section{Nursing actions as being-with-the-other}

Most hospitalizations in the unit are based on the desire of caregivers or people who feel at risk with the presence of the female adolescent users. In general, according to the nursing team, they do not recognize the use of psychoactive substances as harmful, they do not identify the risks that they pose and that can pose to others:

[...] without a critical sense of the risks they are taking, the risks they are subjected to violence [...] I just smoked a joint, that's more or less quite normal (14).

What they experience is very dangerous and sometimes they have no idea, they think they will be the favorite of the gang boss, the first lady of the place, and then we try to reverse this idea (115).

Care is a relational encounter that involves the "I", the "other" and the "we", forming a necessary triad for the constitution of knowledges, regardless of the scientific field in which it is inserted. But how to operate this encounter if not everyone involved is available? ${ }^{(10)}$

Such fact requires a discussion about caring and being cared for, understanding that one completes the other, which implies an affective response. Although the commitment is explicit for the caregiver, the receptivity to the other is not necessarily present for the person being cared for, as evidenced in the present study ${ }^{(11)}$.

The actors are situated in the hospitalization lifeworld in a face-to-face relationship, in which there is an intention to provide care. However, it is evidenced a weakness in the reciprocity of perspectives between those involved, which can be justified, in part, by the majority of admissions being contrary to the will of the adolescents.

This context reinforces their desire to not tell their stories, which are so often marked by negligence, abuse, violence. They do not realize the meaning of sharing their biographical situation with the nursing team, as a form of care.

Even in the face of the adolescents' silence, one of the highlights in the interviews was their health condition upon 
hospital admission, whether due to abusive use and/or other situations closely linked to it, such as exposure to violence, prostitution, abandonment at home, at school, among others, which highlights the complexity of chemical dependency. A greater appropriation of the past and the general plan in which the person's action is located allows the observer to draw more reliable conclusions about the subject ${ }^{(7)}$.

\section{[...] they are chemical dependent, but there are some with conduct disorders, depression due to drug and family problems, there is a lot involved in this. [...] some arrive in terrible conditions (16). \\ [...] due to the fragility that they come to the unit, some- times they are from the street, many are mistreated so, we try to give as much guidance as possible, although they do not accept it, sometimes they come with resistance due to what they go through on the street (112).}

In the face-to-face relationship, it can be said that the participant becomes aware of the person in front of him, that is, there is "guidance by you", which consists of intentionally addressing the other person, which does not imply be aware of what goes on in the other's mind ${ }^{(7)}$.

Being together and appropriate to the world of life that we share with ours allows us to establish a therapeutic relationship, but that is only complete when there is appropriation of what is happening with the other person, the possible way for this being the establishment of dialogue.

For nursing, the main professional action is care. Care is considered an art developed by the subjectivity of each "being" constituted by their personal position, their choices, their actions and the way they perceive the other in life ${ }^{(10)}$.

In addition to dealing with issues of detoxification and withdrawal syndrome, the nursing actions in the unit also seek to meet the integral dimensions of the internals, betting on the establishment of dialogue:

I try to get as close to them as possible to say that everything has its time and that we are here to help them mature in all their wrong ideas and try to show them the right way (11).

[...] it is not always just drugs, they must be treated in full, so they may have problems of physical order, they may have a sexually transmitted disease (19).

They are young people who are just, let's say, not mature yet, so they return, then we try to talk again, but it's hard due to their experience [...] it's a lot of immaturity, it's a lot of suffering, some end up in death (112).
Health work is committed to society and to the direct needs of the user, it is centered on live work, which operates with degrees of uncertainty, present in the encounter. A meeting that exists between the one who cares (producer agent with his tools, knowledge and equipment) and the one who is cared for (consumer agent with their intentions, knowledge and representations), which makes the second also the operator of his autonomy ${ }^{(12)}$.

When talking about care in adolescence, it is taken into account beings in development and who should have contact with welcoming people, preferably in their families, operating on feelings of identification and belonging. But, unfortunately, in many testimonies, it can be seen how the family is unable to offer protection to these adolescents, since the family nucleus is sick:

A wonderful girl, but the mother with drug problems, so she was living with father and two brothers; the very fragile father (16)

The lack of parents, they often died or use drugs too, so I know how difficult it is [...] (114)

In the statements below, it is evident the bet, the emotional investment in adolescents by professionals, which refers to the biographical situation of the same ones who trigger the contents of their other roles as father and mother, or even remembering their adolescence, which directs for a humanized action.

Who is a grandmother like me, we are moved by this, we are concerned with providing support that they do not have abroad, affection, a word of encouragement or a stimulus that is for them to try to get out of this (117).

When I was an adolescent, llearned to knit, crochet, paint, then Ilearned how to make my own eyebrows, fix the hair [...] I wanted them to have what I had as a teenager [...]। want them to absorb it a little, of what they need (121).

Transpersonal care marks the relationships, both in the position of caring, educating and showing the way, enabling a vision of the whole, but not to generalize, but to consider the individual as a unique and special being, extrapolating technical care, making room for an expanded, attentive, and affectionate care. Thus, dialogue, listening, hugs and affection are important therapeutic resources ${ }^{(11)}$.

Caring is constituted beyond techniques; it involves feeling, knowledge and moral aspect. And it becomes authentic care when nursing professionals, in addition to responding to 
care needs, responsibly seek to develop, restore or increase care for themselves and others in the best possible way ${ }^{(11)}$.

Regarding self-care, the adolescents may not have had a moment to reflect on relationships, the repercussions of the harmful use of psychoactive substances in their lives. Nursing understands how fundamental it is to develop educational actions related to body care and behavior. The following speeches clarify the above exposed:

I always say to them, this is the place you must reflect the pros and cons that you are going through in life, it is not punishment as they sometimes think. Even weleft here with another thought in relation to you, when you are cool, we leave here well (111).

It would be as if hospitalization served as a reflection from which they have time to absorb everything they went through and, at the same time, reflect on a possible change in habits[...] (I20).

In the present research, the interviewees identify that in the psychiatric hospitalization of female adolescent users of psychoactive substances, attention is a differential in care, which can be divided into observing the girls' behavior and being with them, realizing their needs.

Regarding the behavior observed by the interviewees, it is highlighted, mainly, tje changes: isolationist behavior, risk of treatment abandonment and verbal and/or physical aggression. Nursing is present 24 hours a day: in many cases, they are the first to identify changes, which, when recognized early on, allow preventive measures that reduce negative health problems for adolescents and other actors present, as shown in the following statements:

\section{[...] by the time we work with them, we know when a girl will go into crisis or when she will calm down (I3). \\ Sometimes they are aggressive, they don't want to talk, they also have to respect this moment, not wanting to be invading, because I don't think it's appropriate, it won't have any effect either (115).}

After we medicate, we are more in control, seeing if it is ok, sometimes they fight, grab each other, give each other punches, they all want to run away, so we are very careful, to have our look. We always try to be together (118).

But despite the early identification of signs and symptoms, preventive intervention does not always occur, which may be due to the distance between Nursing and other professional centers. Despite countless efforts for a more horizontal and interdisciplinary work process, as brings the text of the National Humanization Policy, which provides for overcoming the fragmentation of work relations, development of multi-professional dynamics, encouragement of transversality and groupality ${ }^{(13)}$.

The greatest difficulty we have while nursing is often with the rest of the multi-professional team. Because the medical team thinks in a way, but it is nursing that spends 24 hours, we are not heard (11).

We are kind of pruned, like, observing, giving affection or a lot of closeness, let's be honest here we are not very valued, we are doing our job because we like it (112).

In hospitalization, it was possible to verify how the interviewees are far from a shared communicative environment, which is a common place established by the understanding that the subjects reciprocally motivate each other in their activities $^{(7)}$. In the statements, there is a lack of recognition, the work centered on professional core, which undoubtedly reverberates in the quality and satisfaction of the work.

In the hospital scenario, there is the supremacy of hard and light-hard technologies, which are shown by the high technological density of the devices and the existence of care protocols that aim to regulate and control variables that can compromise diagnostic excellence and quality of treatment. Extremely valuable when the focus is the disease, but incomplete when we put the "disease in parentheses" ${ }^{\prime \prime(14)}$.

In the study scenario, it was perceived the fragility of the nursing interaction with other team members, but, on the other hand, with the adolescents it is shown to be a powerful care tool, as shown in the following statements:

We try to talk to them, try to bring them to us, so they can have some confidence, tell a little of their story, we exchange a lot of experience, in adolescence I wasn't easy either, adolescence was terrible (17).

I think it's not just medication that will help but trying to talk a lot about how young they are, that they have a future, that they can do whatever they want (110).

From the above, it is possible to identify that the dialogue between the nursing team and the adolescents is present in the establishment of care, of the therapeutic relationship. Care is a light technology that, through the respectful relationship, the encounter with the other, considers humanitarian, moral values, human and contextual aspects, without failing to identify needs ${ }^{(15)}$. 
When the other's speech and our listening are experienced as a vivid simultaneity and we participate in the immediate present of the other's thought, we are faced with the general thesis of the alter ego in which a stream of consciousness takes place, whose activities I can perceive in the present, through my own simultaneous activities ${ }^{(7)}$.

Listening, getting to know the life stories of the adolescents, makes it possible for nursing to have access to some aspects that help them to broaden their perception regarding the use of psychoactive substances in adolescence, surpassing the common and discriminatory sense that accompanies chemical dependency.

Nursing plays an important role in the adolescents' adaptation period during hospitalization, explaining the functioning of the service, facilitating the approximation with the other inmates and the team. It is noticed how much the interviewees take dialogue, therapeutic listening as their care, subtracting the historical weight that nursing still incorporates in Psychiatric Clinic and Mental Health, in which it was only concerned with symptom control, bodies and institutions.

Thus, among so many challenges, it is possible to point out effective communication intertwined with a communicative act that presupposes a collaborative activity of the actors: nursing professional, user and multi-professional team $^{(16)}$. In this way, being in the world of life is much more than being present, it is necessary to be present through intentionality towards the other, it is sharing what has been experienced, it is allowing oneself to be influenced and to influence the other.

\section{Collective nursing actions as potential for shared act}

The unit has graffiti walls, the floor designed with hopscotch sets, it is a place that seeks to be welcoming, but it is a closed unit, without an external patio, located on the fourth floor of the hospital, it has few audiovisual resources, which, in a way, it limits the offer of activities, bringing idleness to the fore.

Nursing is the professional core that works with teenagers 24 hours a day, sharing the moments when the hospital slows down, such as late afternoons, evenings, weekends, and holidays.

The internal ones, in addition to the issues of adolescence, are crossed by chemical dependency, that is, they are eager to minimize cravings, abstinence, to do something to put an end to idleness and the slowness of time. Paradoxically, nursing is present in collective spaces, but participates little in groups and workshops:
On the weekend there is nothing to do with them (15).

The stopped girls, sometimes for an entire afternoon without having an activity, only with pencils to paint, we see how idle they are, here there is the possibility of having a nice servisse (17).

Think about it, some adolescents locked up here, spend most of their time on the street, then they stay locked up without activities, but then we try to do activities with them, even not being recognized, we do it (112).

It is important to point out that the hospitalization team only includes the presence of nursing in the periods described above, and occupational therapists and social workers, in addition to having their workloads shared with the adult unit, work from Monday to Friday. Faced with such situations, interviewees are encouraged to review their work process, predominantly centered on individual actions, and take collective actions developed by Nursing in Mental Health and Psychiatry, which are supported by Resolution 0599/2018(17), namely: conducting and coordinating therapeutic groups, and, in the case of nursing technicians, participating in group activities with other professionals from the Mental Health team. Interviewees pose some questions to be discussed:

On the weekend, the nursing technician invents an activity and picks up brown paper for them to paint because on the weekend there is nothing to do with them (15).

We do the specialized service of the nursing technician and a few more workshops that we used to do but nowadays they are no longer done, we stopped doing it due to the charges (17).

The first thing is to check the signs, see if everything is right, then the medications arrive and then attention is given to them, doing some activities such as playing cards, painting the nails, these things that it has in the unit (110).

In the speeches, it can be seen how much the activities developed show more of a playful character than a properly therapeutic one for the interviewees. Regarding the speech that brings the charge, it refers to the lack of knowledge of other professionals to understand that group activities are attributions of nursing and that in no way would they be invading the scope of work of other professionals. On the other hand, it is also observed that some participants do not recognize groups and workshops as nursing activities, but that, in view of the daily idleness of hospitalization, they end up performing these activities. 
The lack of understanding that groups and workshops are actions of nursing can be explained, in part, by the trajectory of the profession in services, which has historically been influenced by the medical domain, which has the power to prescribe, and, on the other hand, religious, who preached subservience, abnegation, docility and affection ${ }^{(18)}$. Elements that were welcomed by nursing, predominantly exercised by women, and that soon assumed a more prescriptive care for each person.

The group activities and workshops in Psychiatry and Mental Health are usually assigned to psychologists, social workers and occupational therapists. In the unit in question, it is perceived how much the adolescents spend periods in idleness. In this way, nursing reveals itself as a potential nucleus for collective practices.

It is essential to raise awareness of nursing, as well as the development of training, in the form of permanent education, for the appropriation of practices and fundamentals of group processes, as well as awareness with other members of the hospitalization team so that they recognize and support as a legitimate and well-founded nursing practice. In group activities there is an intentional interconnection between those involved, in which one should motivate the other. People are perceived to each other, not as objects, but as counter-subjects who, through communicative acts, the "I" turns to others, apprehending them as people who turn to them, and both understand the phenomenon ${ }^{(7)}$.

The development of these group practices could reflect a powerful activity that articulates the adolescents' demands, which should be properly planned, with objectives to be achieved, contributing to nursing recognize their collective actions as an important part of care.

\section{Nursing actions as expectations and challenges}

Concomitantly with caring for girls, there is an intentionality directed towards themselves, in which the Nursing team, when perceiving weaknesses and potentialities related to the development of their actions, also manages to bring expectations and challenges related to their work.

Difficulties are recurrent in the interviewees'speeches and are directly linked to the organization of the interdisciplinary work process, more specifically in the lack of horizontality in relationships, since not everyone can be heard and have their opinions considered.

The greatest difficulty we have while Nursing is often with the rest of the multidisciplinary team. Because the medical team thinks in a way, but it is Nursing that spends 24 hours, we are not heard (17).

The difficulty is for us to stop in routines, created by people who do not use this routine and often do not know, the potential that we (Nursing) have here inside [...] (17).

There are always difficulties, we have interaction, it's a whole team, so most of the time we think differently and act differently, we try to adapt (I8).

In hospitalization, although exist a physical approximation between the actors, there is no guarantee of intersubjectivity, the establishment of integrative relationships, in which some motivate each other ${ }^{(4)}$.

In the statements, there is a lack of recognition permeating the relationships and actions developed. Another element that refers to the complexity of working in the unit is the appropriation of the themes: adolescence and chemical dependency by the interviewees and the importance of having and following service routines from a therapeutic and organizational perspective of the space. Which places permanent education as a powerful resource to work on these issues, but, however, what can be seen in the following statements is still a process to be discovered:

We are a teaching hospital, so we change from period to period, there are trainees, residents, then there is change, so then we have to start all over again (14).

There are people who are unprepared to work with drugs because they think that's how they say without shame, they're complaining here, but what were you doing on the street? (15).

Every time they are doing a different routine, there is no way for that, because we have to follow a routine, of course there have to be some changes, but there are things that are basic (sic) (16).

Following an interdisciplinary perspective, at the unit there are weekly meetings for the discussion of administrative cases and subjects, and also monthly, these so-called collegiate, which could be spaces for permanent education. But not all workers are able to participate and some do not recognize it as a place for sharing:

We put something on the agenda, we want to discuss, and they don't let us talk, so I don't like to participate in these collegiate bodies, for me it doesn't matter at all, I'm very frank to talk (I6). 
We have Wednesday meetings, which is the round where we can talk, yes, but as the meeting takes place in the morning, it is usually the morning team that is there. So, it is difficult to talk to everyone, the other professionals (from the other shifts) are a little isolated and end up not participating in the decisions, they are left out, they do not know what is happening (114).

In the speeches, it is perceived that a scheduled meeting is not necessarily a collective space that guarantees the horizontality of exchanges and the linear construction of knowledge. It is a challenge to see the other and oneself as a subject actively involved in the care process.

From a retrospective look that accessed the reasons why the interviewees were able to highlight the weaknesses and potential of the actions developed, but also allowed for a future movement - reasons for identifying expectations.

Regarding expectations, there is a search for the improvement of adolescents, but issues that arise from the search for autonomy, protagonism, visibility and recognition of Nursing professionals as social actors in the life world of Psychiatry and Mental Health are also witnessed.

That we could work with a multi-professional team so that everyone had a vision that reached the same point (14).

I hope that we can accomplish more, I hope that we have the opportunity to work and that people have a better mindset, open their minds to thi s(17).

Being recognized, but we are not, but then we keep going (112).

Thus, given so many future possibilities that can be called goals at hand, there is a convergence of expectations of the being that are intensely influenced by the determined biographical situations of each person endowed with their knowledge: we speak here of biography, subjectivity, singularity, individuality and motivations ${ }^{(16)}$

Among so many complexities placed in the unit - adolescence and chemical dependency - it is important that there is an appropriation of workers on the themes, which makes permanent education an interesting resource, as well as pointing out the continuity of routines as therapeutic for internal ones and for the good progress of the unit.

\section{GINAL CONSIDERATIONS}

The present study sought to understand the significance of the actions of the nursing team in a psychiatric inpatient unit for female adolescent users of psychoactive substances, and it was possible to identify that these actions are established through intersubjective relationships, guided by bonding and dialogue. The study pointed out the need for nursing to enhance its actions by expanding the offer of collective therapeutic activities in line with the psychosocial care model. Regarding the meaning of the actions performed by the professionals, the study contributes to the production of knowledge in the field of mental health nursing, based on the unveiling of the intersubjective relationship between adolescents and the nursing team.

The participants characterize what is typical of their action as unique and empathetic to each adolescent in the context of hospitalization for substance abuse treatment. The nursing team initially starts from the recognition of the vulnerability situation that the adolescents are exposed to. Thus, they adopt an empathetic posture, of attentive listening and openness to dialogue with them in order to provide care. It provides a space for ambiance with the unit and guides its actions, especially in individual approaches in the daily relationship of work, and eventually performing collective actions (playful and self-care), yet lacking a therapeutic connotation, as they are carried out empirically (without theoretical support) and motivated by the idleness experienced by the hospitalized adolescents.

The study results contribute to reflections on the therapeutic potential of nursing professionals for mental health care for female adolescent users of psychoactive substances. These findings reveal a latent need for nursing professionals to enhance their actions as an area of knowledge to attend and care for these adolescents, by expanding the offer of collective therapeutic activities in line with the psychosocial care model. The permanent education space already institutionalized in the service can support the overcoming of this obstacle. These findings can serve as inspiration for other realities similar to the study scenario.

It is considered, as a limitation of the study, the fact that the phenomenon studied does not include the perspective of female adolescent users of substances to compose the perspective of nursing professionals. Thus, are suggested other studies on the theme directed at this audience. 


\section{REFERENCES}

1. Andrade ME, Santos IHF, Souza AAM, Silva ACS, Leite TS, Oliveira CCC, et al. Experimentation with psychoactive substances by public school students. Rev Saúde Pública. 2017;51:82. doi:https://doi.org/10.11606/s1518-8787.2017051006929

2. Ribeiro JP, Gomes GC, Santos E0, Pinho LB. Specificities of care to the adolescent crack user assisted in the psychosocial care network. Esc Anna Nery. 2019;23(2):e20180293. doi:https://doi.org/10.1590/2177-9465-EAN-2018-0293

3. Corso DL, Corso M. Adolescência em cartaz: filmes e psicanálise para entendê-la. Porto Alegre: Artmed; 2018.

4. Teixeira LA, Freitas RJM, Moura NA, Monteiro ARM. Mental health needs of adolescents and the nursing cares: integrative review. Texto Contexto Enferm. 2020;29:e20180424. doi: https://doi.org/10.1590/1980-265X-TCE-2018-0424

5. Oliveira RM, Siqueira Júnior AC, Furegato ARF. Enfermería en unidad de internación psiquiátrica. Cultura Cuidados. 2020 [cited 2021 Jan 18];24(57):250-63. Available from: https://ciberindex.com/index.php/cc/article/view/57250cc

6. Silva TG, Santana RF, Dutra VFD, Souza PA. Nursing process implantation in mental health: a convergent-care research. Rev Bras Enferm. 2020;73(suppl 1):e20190579. doi: https://doi.org/10.1590/0034-7167-2019-0579

7. Schutz A. A construção significativa do mundo social: uma introdução à sociologia compreensiva. Petrópolis: Vozes; 2018.

8. Grupo Hospitalar Conceição (BR) [Internet]. Porto Alegre; HNSC; c2020 [cited 2021 Jan 18]. Internação Hospitalar; [about 1 screen]. Available from: https://www. ghc.com.br/default.asp?idMenu=cartacidadao\&idSubMenu=14

9. Camatta MW. Ações voltadas para saúde mental na Estratégia de Saúde da Família: intenções de equipes e expectativas de usuários e familiares [tese]. Porto Alegre (RS): Universidade Federal do Rio Grande do Sul; 2010 [cited 2021 Jan 18]. Available from: https://lume.ufrgs.br/bitstream/handle/10183/27895/000767787. pdf? sequence $=1 \&$ is Allowed $=y$
10. Borges RF. Cuidado educativo: relações e possibilidades de uma práxis transformadora no ensino superior [tese]. Porto Alegre (RS): Pontifícia Universidade Católica do Rio Grande do Sul; 2015 [cited 2021 Jan 18]. Available from: http://tede2.pucrs.br/tede2/bitstream/tede/6129/2/470412\%20-\%20 Texto\%20Completo.pdf

11. Waldow VR. Enfermagem: a prática do cuidado sob o ponto de vista filosófico. Investig Enferm Imagen Desarr. 2015;17(1):13-25. doi: https://doi.org/10.11144/ Javeriana.IE17-1.epdc

12. Merhy EE, Baduy RS, Seixas CT, Almeida DES, Slomp Júnior H, organizadores. Avaliação compartilhada do cuidado em saúde: surpreendendo o instituído nas redes. Rio de Janeiro: Hexis; 2016.

13. Ministério da Saúde (BR). Secretaria de Atenção à Saúde. Política Nacional de Humanização: Humaniza SUS. Brasília, DF: Ministério da Saúde; 2013 [cited 2020 0ct 1]. Available from: http://bvsms.saude.gov.br/bvs/publicacoes/ politica_nacional_humanizacao_pnh_folheto.pdf

14. Merhy, EE. Saúde: a cartografia do trabalho vivo. 3. ed. São Paulo: Hucitec; 2002.

15. Almeida Q, Fófano GA. Tecnologias leves aplicadas ao cuidado de enfermagem na unidade de terapia intensiva: uma revisão de literatura. HU Rev. 2016 [cited 2020 0ct 1];42(3):191-6. Available from: https://periodicos.uff.br/index.php/ hurevista/article/view/2494/891

16. Alves KYA, Bezerril MS, Salvador PTCO, Feijão AR, Santos VEP. Effective communication in nursing in the light of Jürgen Habermas. Rev Min Enferm. 2018;22:e-1147 doi: https://doi.org/10.5935/1415-2762.20180078

17. Conselho Federal de Enfermagem (BR). Resolução nº 0599/2018, 19 de dezembro de 2018. Aprova Norma técnica para atuação da Equipe de Enfermagem em Saúde Mental e Psiquiatria [Internet]. Brasília: COFEN; 2018 [cited 2020 Jan 15]. Available from: http://www.cofen.gov.br/wp-content/uploads/2018/12/ RESOLU\%C3\%87\%C3\%830-599-2018.pdf

18. Coelho I. Os hospitais no Brasil. São Paulo: Hucitec; 2016. 
The study is the result of a doctoral thesis entitled Nursing actions in a psychiatric inpatient unit for female adolescent users of psychoactive substances; presented to the Postgraduate Program in Nursing at the Universidade Federal do Rio Grande do Sul (UFRGS).

\section{- Authorship contribution:}

Conceptualization: Rita Mello de Mello; Jacó Fernando Schneider; Cíntia Nasi; Marcio Wagner Camatta; Eglê Rejane Kohlrausch; Annie Jeanninne Bisso Lacchini. Formal analysis: Rita Mello de Mello; Jacó Fernando Schneider; Cíntia Nasi; Marcio Wagner Camatta; Eglê Rejane Kohlrausch; Annie Jeanninne Bisso Lacchini. Investigation: Rita Mello de Mello; Jacó Fernando Schneider.

Project administration: Rita Mello de Mello; Jacó Fernando Schneider; Cíntia Nasi; Marcio Wagner Camatta; Eglê Rejane Kohlrausch; Annie Jeanninne Bisso Lacchini.

Writing-original draft: Rita Mello de Mello; Jacó Fernando Schneider; Cíntia Nasi; Marcio Wagner Camatta; Eglê Rejane Kohlrausch; Annie Jeanninne Bisso Lacchini; Tainá Moreira de Mello.

Writing-review \& editing: Rita Mello de Mello; Jacó Fernando Schneider; Cíntia Nasi; Tainá Moreira de Mello.

The authors declare that there is no conflict of interest.

\section{- Corresponding author:}

Rita Mello de Mello

E-mail: ritamello42@gmail.com

\section{Editor-in-chief:}

Maria da Graça Oliveira Crossetti 